The following paper is intended to spur further discussion in the forthcoming issue of Gestalt Theory

Anton Yasnitsky

\title{
Cultural-Historical Gestalt Theory and Beyond: Toward Pragmatic Anthropology
}

\section{Topic and Aim}

This paper continues the discussion of the Gestalt tradition as an "informal personal network" and the "circles" of its representatives, originally proposed by Yasnitsky $(2021 \mathrm{~d})^{1}$ and presented in the preceding article, which came out in this special issue of the journal (Yasnitsky, 2021b). As has been demonstrated, the popular image of the Gestalt theory is fraught with numerous and diverse receptions, interpretations, and social constructions; this paper's aim is to present a discussion of yet another reception and, then, reflect on its impact on this intellectual tradition from a theoretical standpoint.

\section{From History to Theory: The Soviet Marxist "Cultural-Historical Gestalt Theory"}

One of such social receptions of the Gestalt theory took place in the context of the "Soviet Marxist psychology" (Yasnitsky, 2021a), specifically within the frame of what I earlier termed a "cultural-historical Gestalt psychology" (Yasnitsky, 2012) — which seems to have been emerging as the result of a "beginning of a beautiful friendship" between the "Vygotsky Circle" and the Gestaltist "Berlin Circle" members (Yasnitsky, 2016)_and even "Soviet Gestaltism" of the Soviet "Vygotskians", but not exclusively them (Yasnitsky, 2021d). As far as Vygotsky is concerned, the studies of the "Vygotsky(-Luria) Circle" — which in my present view would be better characterized as a "network" rather than a "circle" in its narrower meaning as used in this very paper and its prequel (Yasnitsky, 2021b) revealed and presented a few of the "peripheral members" of the Circle/network. By the same logic, from the perspective of the "Berlin Circle", the Soviet scholars of "Soviet Gestaltism" can be regarded as the peripheral members of the larger "Gestaltist network" with its intellectual hub in Berlin. Then, the inclusion of the Soviet group in this larger community is yet another reason to somewhat revise

\footnotetext{
This important (at least, for its author) — and somewhat lengthy_text was first orally presented in the spring of 2021 as a Guest Lecture at the United Arab University in Al Ain and is, in fact, a manuscript of a book in progress; available online at http://individual.utoronto.ca/yasnitsky/texts/Yasnitsky_2021_revNoRev.pdf
}

O Open Access. ( 2021 Anton Yasnitsky, published by Sciendo. (c) BY-NC-ND This work is licensed under the Creative Commons Attribution NonCommercial-NoDerivatives 4.0 License. 
and adjust our views on the possible theoretical meaning of this larger German/ Soviet network of like-minded individuals, yet cum grano salis and also necessarily keeping in mind the differences between them. Both ways of analysis are possible and quite legitimate: dissimilarities and similarities are equally important. Yet, differences notwithstanding, the following sections will be treated from the perspective of this very-specific and idiosyncratic - Soviet positive reception of Gestaltism that came about on the grounds of their theoretical and methodological similarities (and resemblances) and the search for, figuratively speaking, the "lowest common denominator", which I believe are of considerable promise in the context of the tasks and challenges facing psychology in the 21st century, specifically, the lack of and the need for a unifying general psychological theory, yet to come about, possibly, as a transdisciplinary field of knowledge under the label of "pragmatic Anthropology", as I proposed earlier (Yasnitsky, 2021d). The discussion is based on my earlier-somewhat tentative and preliminary-text on "Field theory", which was written for and published in a multivolume book titled "Encyclopedia of Critical Psychology" (Yasnitsky, 2014). The word "critical" in the book's title is not incidental, and that small paper was intended to discover the unusual facts and perspectives, the "anomalies" that are frequently ignored in traditional narratives. Now, I would like to revisit this earlier research, question some of its proposals, and expand its findings beyond the limits of its original, relatively narrow topic.

The following part of this paper suggests a few theoretical points related to Soviet-German-American intellectual proximity and convergence, but inevitably—partlybecause of thelimitson paperlength—onlyin the mostschematic, fragmented, and tentative form, in a few broad brushstrokes, for the purposes of providing the reader food for thought, the grounds for further critical discussion, and, whenever needed, unbridled yet fair, rational,, and argumentative criticism.

\section{Gestalt Theory as a Cultural Anthropology of Personality}

Overall, Vygotsky's science was clearly some sort of anthropology-cultural anthropology, to be precise- even though the word as such is definitely not an element of his vocabulary and despite his identification as a psychologist. Just consider the title of the book (Vygotskii \& Luria, 1930): "Etudes on the History of Behavior. Ape, Primitive, Child" (alternatively, the first word of the title can be translated as "essays" or "studies"). This is the book of 1930 by Vygotsky (the author of roughly a half of the book, the first two smaller chapters out of the three: on "ape" and "primitive", respectively) and Luria, who was the author of the last chapter, which, unlike the first two, by its author's admission, was "based ... mainly [on] our material gathered in the experimental studies of child behavior" (Vygotsky \& Luria, 1993, p. 37). The book, as we know it, comprises three 
chapters. Originally, another chapter was presumably planned that-should it have ever been written-would have been the pinnacle of the whole project. It was supposed to discuss yet another evolutionary step above the actual human being: the "sverkhchelovek" of the Communist future, also known as a "new man", or the "superman", as Vygotsky preferred to call this new evolutionary step in his numerous writings, where it clearly stems from "Übermensch" in German, an "overman" of Friedrich Nietzsche-the "philosopher, psychologist, antichrist" (Kaufmann, 1950)—considering the historical origin of this idea in Vygotsky's thought via mediation and its Bolshevik interpretation of Leon Trotsky. Yet, for some reason, the substantial discussion of the Communist "superman" never made it to this—or, for that matter, any other-book of Vygotsky or Luria. The promise of a Communist future "science of superman" of Vygotsky never made it to a "concrete science" and remained a utopia until these very days as much as it was in Vygotsky's lifetime (Yasnitsky, 2019).

As the Preface to the English edition of 1993 attests, "the appearance of this book [is] a timely contribution to scholars in many fields: psychology, education, psycholinguistics, and cultural anthropology" (Vygotsky \& Luria, 1993, p. xv) and, then, in turn, in the same author's Translator's Introduction, "Vygotsky was also influenced by the work of Western European psychologists, sociologists, and anthropologists" (Vygotsky \& Luria, 1993, p. 4). In essence, most of this book of 1930 is a popular second-hand exposition of somebody else's ideas related for the Soviet mass readership that in its majority did not have reading skills in German (as well as other foreign languages). The two particular sources are especially interesting in the context of our discussion. Chapter 1 is mostly a popular discussion of Wolfgang Köhler's classic on the psychology and behavior of the "ape" (Köhler, 1925), original German publication of 1917, then, of 1921; in Vygotsky and Luria's own words: "The first essay is based on the materials collected by Köhler in his famous research; the second essay includes material on ethnic psychology collected in the works of ... Wertheimer... and many others" (Vygotsky \& Luria, 1993, p. 37). The latter refers to Max Wertheimer's earlier paper on the thinking of primitive people (Über das Denken der Naturvölker) (Wertheimer, 1912). Indeed, quintessentially a cultural-anthropological study, this paper of Wertheimer reveals his interests well beyond the confines of his "Gestalt psychology" as it is traditionally represented in the literature. Furthermore, this paper is apparently neither the sole, nor incidental, study of the kind: the other one is a discussion of the music of minority indigenous group of people in Sri Lanka, which had come out 2 years earlier (Wertheimer, 1910). The plot thickens even in a more interesting way, considering the fact that, for his programmatic publication on the Gestalt theory of 1925, a collection of only three earlier works republished between the covers of a book, in retrospect, the established founder of a novel and 
increasingly well-known psychological theory, Max Wertheimer picked one of these two "ethnographic" (or "cultural-anthropological", as we might call them) studies as a representative example of what the entire "Gestalttheorie" stands for (Wertheimer, 1925). If we hold this Vygotsky-Luria's book structure as a conceptual frame for their cultural anthropology—as expressed by their tripartite formula "ape-primitive-child"-then another Gestaltist piece of puzzle perfectly finds its place within it: the book by Koffka on child developmental psychology (Koffka, 1924), original German publication of 1921.

The two mentioned books-Köhler's, on the "mentality of apes", and Koffka's, on child psychology - were translated and published in Russian (Keler, 1930; Koff$\mathrm{ka}, 1934)$ upon the initiative and due to the most active, direct participation of the primary proponents of and advocates for Gestaltism on the Russian soil (Yasnitsky, 2016), the members of the Vygotsky — Luria Circle as text translators, the books' editors, and the authors of the introductory or accompanying articlessuch as Vygotskii (1930a, 1934). These two books had remained the only book publications of the primary works of German Gestalt psychologists available to Russian readers throughout virtually the entire history of the Soviet Union until 1987, when Max Wertheimer's posthumous book on "productive thinking" (Wertheimer, 1945) came out in Russian translation, too (Vertgeimer, 1987).

\section{Concrete Personality in Concrete (Social) Settings}

Here is an important point: the "anthropology" we are dealing with here is not exactly the kind of anthropology as a scholarly discipline that we well know these days with its focus on larger groups of human beings, such as tribes, communities, nations, etc. Instead, it is best understood as a transdisciplinary framework for a holistic, all-round study of a human being; a similar approach-yet highly unsuccessful in any sense: intellectual, scholarly, and political—was presented in the extinct science of pedology in Europe, America and, finally, Soviet Union (Byford, 2021). Moreover, unlike the disciplinary anthropology of our days, this field of knowledge would become the science of individual personality, ultimately capable of dealing not with a personality in some abstract sense (e.g., that of a "subject"), but with each and every personality in his or her most concrete social circumstances. After all, the close similarity between the requirement of "practicality" imposed on Soviet science by the Bolshevik (Communist) political regime in the Soviet Union (Krementsov, 1997) and the maxim "There is nothing more practical than a good theory", famously ascribed to Kurt Lewin (but not only to him), provides additional food for thought.

The focus on personality was a quite common theme in Vygotsky's (and other Soviet scholars') work, most notably in Sergei Rubinstein's foundational for the entire Soviet Marxist psychology oeuvres (Yasnitsky, 2021c). In retrospect, this 
approach-not always explicit in their publications-was generally quite common among German Gestaltists. Consider just one example: the very first book that Kurt Lewin published in English in the United States quite unambiguously bears the word "personality" on its cover: "A Dynamic Theory of Personality" (Lewin, 1935). One can hardly dismiss this fact as insignificant. In addition, I would argue, this would be a cultural anthropology of personality that hinges upon the key notions of value, attitude, belief, etc.

\section{Society and Ideology: "The Place of Value in a World of Facts"}

We learn quite a lot about Gestalttheorie from the studies conducted in Germany and the German publications before 1933. Later publications in English, such as wartime Kurt Lewin's or Wolfgang Köhler's papers of the post-WWII scene, are certainly also informative. Yet, the works of the main proponents of this theory during their transition from the German to the American intellectual milieu are particularly important. Let us consider these closer now.

German researchers' move to the United States (and a few other countries) in the mid-1930s-their separation from their intellectual "natural habitat" and integration into a foreign academic culture-exposed "the other side" of their thinking and axiomatic belief system that had remained tacit within German academic tradition and would pass as common knowledge and a broadly shared axiomatic knowledge base, yet, not common knowledge anymore in their new land of work and residence. Unlike during their German period, with its predominance of studies in the psychology of perception (as well as in a wide range of subfields of experimental psychology, of course), the American period turns them to explicitly discussing the topics of meaning, significance, value (Koffka, 1935), the "place of value in a world of facts" (Köhler, 1938), and the like. This is how Koffta describes the situation of the cultural differences in science as experienced by his German compatriots in the process of their transition to the United States:

SIGNIFICANCE, VALUE. We turn to the last of our categories: significance. What we mean by that is harder to explain than the two previous concepts, and yet here lies one of the deepest roots of gestalt theory, one which has been least openly brought before the English-speaking public. The reason for this is easy to understand. There is such a thing as an intellectual climate, and the intellectual climate, just as meteorological, varies from country to country. [p. 18] And just as the growth of a plant depends upon the PHYSICAL climate, so does the growth of an idea depend upon the intellectual climate. There can be no doubt that the intellectual climates of Germany and the United States are widely different. The idealistic tradition of Germany is more than an affair of philosophic schools; it pervades the German mind and appears most openly in the 
writings and teachings of the representatives of "Geistwissenschaften", the moral sciences (Koffka, 1935, pp. 17-18).

Then, Koffka continues with the discussion of what seems to be the foundational distinction between the two national academic cultures:

The meaning of a personality prominent in history, art or literature, seems to the German mind more important than the pure historical facts which make up his life and works; the historian is more interested in the relation to the events on the plan of the universe than in his relations to the events on the planet. Contrariwise, in America, the climate is chiefly practical; the here and now, the immediate present with its needs, holds the centre of the stage, thereby relegating the problems essential to German mentality to the realm of the useless and non-existing. In science this attitude makes for positivism, an overvaluation of mere facts and an undervaluation of very abstract speculations, a high regard for science, accurate and earthbound, and an aversion, sometimes bordering on contempt, for metaphysics that tries to escape from the welter of mere facts into a loftier realm of ideas and ideals (Koffka, 1935, p. 18).

The introduction of "Gestalt-theorie" as early as in 1922 (Koffka, 1922) could not have effectively taken place unless a compromise was made. Yet, as of the mid-1930s, this foreign intellectual tradition had firmly established itself within American academia, which allowed, thus, for a fuller exposition of its principles, axiomatic bases, and foundational premises to the American scholarly community:

Therefore when the first attempts were made to introduce gestalt theory to the American public, that side which would most readily appeal to the type of German mentality which I have tried to sketch was kept in the background, and those aspects which had a direct bearing on science were emphasized. Had the procedure been different, we might have incurred the danger of biassing our readers against our ideas. Living in a different intellectual climate[,] they might have taken this aspect of gestalt theory for pure mysticism and decided not to have anything to do with the whole theory before they had had a chance of becoming acquainted with its scientific relevance. At the present moment, however, when gestalt theory has been taken up as a main source of discussion, it seems only fair to lift the old restriction and expose all its aspects (Koffka, 1935 , p. 18).

Finally, in his truly exciting__albeit somewhat stylistically and intellectually troublesome to an American reader, especially that of our times_- "Principles of Gestalt Psychology", Koffka openly offers the main theoretical challenge:

The positivistic interpretation of the world and our knowledge of it is but one possibility; there is another one. The question is: Which is really true? 
Meaning, significance, value, as data of our total experience give us a hint that the latter has at least as good a chance of being the true one as the former. And that means: far from being compelled to banish concepts like meaning and value from psychology and science in general, we must use these concepts for a full understanding of the mind and the world, which is at the same time a full explanation (Koffka, 1935, p. 21).

Not an entirely new trend in Gestalt literature of the 1930s (Ellis, 1930), the topic of "Gestalt psychology and meaning" is, nevertheless, a major advancement as compared with the writings of the "Berlin period", which still needs to be understood as one of the cornerstones of this intellectual tradition in its entirety.

In its most extreme form, this line of theorizing can be found in a politically radical book titled "Psychology and the Social Order", authored by Junius Flagg Brown, an American Gestalt movement activist, a member of the "Gestalt network", a direct student of Lewin, his strong supporter, finally, an early and zealous advocate of his research program in the "psychology of action and affection" in the United States (Brown, 1929). The author was a truly remarkable figure, by North American standards, at least: "in contrast to mainstream positivist psychology with its assumptions of an objective and value-free science, Brown in the 1930 s advocated a politically oriented and value-laden Marxist psychology" (Minton, 1988, p. 165) and, in his book, openly discussed the ideas and actions of impressively diverse political figures such as (in alphabetical order) Bukharin, Engels, Hitler, Kerensky, Lenin, Marx, Molotov, Mussolini, Napoleon, Robespierre, Roosevelt, Stalin, and Trotsky (Brown, 1936). The book has virtually remained unread by the intellectual community until these very days and presents an exciting challenge to our beliefs about "Gestalt theory", yet to be uncovered and understood in its full potential promise.

The focus on these notions strongly resembles Vygotsky's eternal search for a theory of consciousness (Zavershneva, 2014), which, according to the anticipations of Vygotsky of his most mature period of the last year of his life, would focus on the notions of "meaning", "sense", and the processes of "cognizing" and "sense-making", which in Russian derive from the same word "consciousness": "soznanie" (Yasnitsky \& Van der Veer, 2016).

Finally, those readers who are still in doubt with respect to the actual and potential applicability of the Gestalt theory to the issues of society and ideology should be reminded that Kurt Lewin - an important and highly proactive member of the "Berlin Circle" - is widely acknowledged as the "founder of social psychology" on American soil and, particularly, is praised for his presumably Gestaltist and undoubtedly innovative studies in "group dynamics" in the United States. In fact, as a comment aside, this tentative study into "informal personal networks" 
and the "circles" of intellectuals and their associates seems to follow this very scholarly tradition and might count as a direct development of this, Lewinian, "group dynamics" research trend.

\section{Human Development, Historicism, and Dialectical Change}

Vygotsky's historicism is pretty obvious and is well known as one of his most essential axiomatic bases. This was discussed on quite a few occasions in the literature as probably one of the most essential contributions of this author-as well as the whole psychological approach of "Soviet Marxism" - to world psychology and hardly needs any further exposition.

Quite in contrast, the Gestalt theory-according to the popular, traditional interpretation at least-is deliberately and demonstratively ahistoric in its insistence on the priority and permanence of the holistic Gestalts. This might be considered a "Gestaltist bias" and, indeed, this is for what Gestalt psychology ("strukturnaia psikhologiia", or "structural psychology", in Lev Vygotsky's own and idiosyncratic Russian translation and interpretation of the German "Gestaltpsychologie") was often criticized by the Soviet Marxist-minded scholars—such as, for instance, Lev Vygotsky (Vygotskii, 1930b, 1934)—with their bias of the priority of "dialectical approach" and the foundational presumption of social and historical development. And, yet, I would like to offer an alternative interpretation.

True, the idea of a historical development of "Gestalts" can hardly be found on the agenda of the "Berliners" and their associates. I would attribute it to two essential factors. First is the prevalence of physicalist sentiments and biases shared by some (if not all) German Gestaltists, with their deep entrenchment in the contemporary debates in physics and natural sciences, the Zeitgeist, and the hot topics in scientific enterprise of their time. Second, the avoidance of the explicit discussion of a historical change among the majority of Gestaltists might be better understood in the context of clinical and theoretical psychology as the Gestaltists' intuitive rejection of Freudian trends in this field that had great power over the minds of quite a few of their contemporaries. In fact, the Freudian undercurrent in Gestaltism-although unpronounced explicitly-is very much perceived as an implicit reference frame. Consider, for instance, the title of the programmatic book, a collection of just three earlier works that Wertheimer published in 1925 and that seems to be a statement of what, according to its author, Gestalttheorie is presumably supposed to be about. Wertheimer's "Drei Abhandlungen zur Gestaltheorie" (Wertheimer, 1925) is apparently a direct paraphrase of Freud's "Drei Abhandlungen zur Sexualtheorie"(Freud, 1905): presumably, what else other than a mockery and ironic, playful mirroring of Freud's programmatic volume it was intended to be from Wertheimer's standpoint. Similarly, the whole program of research on "Handlungen und 
Affekt" (in a situation "here and now") that unfolded in the "Berlin Circle" on Lewin's initiative and under his supervision appears a clear reaction to (and rejection of) Freudian fascination with the depths of human soul, the "man as a neurotic" bias, and the method of the clinical un-covery and dis-covery of the roots of this presupposed tacit universal neuroticism in the historical past of the individual.

Yet, Gestalt psychology, contrary to its common perception and criticisms, is not that alien from the ideas of historical development, change, and dialectics. Consider, for instance, the whole monograph on the topic of child development by Kurt Koffka with the word "development" (Entwicklung) highlighted in the very title "Die Grundlagen der Psychischen Entwicklung: Eine Einführung in die Kinderpsychologie" (Koffka, 1921). Virtually at the same time as Koffka, Kurt Lewin published his book "Der Begriff der Genese in Physik, Biologie und Entwicklungsgeschichte", still not translated into English and-most regrettably-largely ignored by the scholarly community until this very day (Lewin, 1922). Considering that the book-as well as the theoretical and profound methodological study behind it - was intended by its author as his Habilitation dissertation that - were it successfully defended, which as a matter of fact it was not-would entitle Lewin a full-time professorial position in a university, it is hardly possible to overestimate the importance of this treatise and its impact on the entire "thinking style" of Lewin in his subsequent academic career in psychology. The title translates as "The notion of genesis in physics, biology, and history of development" (alternatively: "evolutionary history") and, the subject matter of the "comparative [study of] science[s]" notwithstanding — as reflected in the book's subheading "Eine Untersuchung zur vergleichenden Wissenschaftslehre" - the author of the treatise clearly demonstrates a quintessentially dialectical approach and an explicit focus on the topics of development, (dis)similarity of the range of states in the process of change, and dialectical transformation. Basically, the same spirit of consistently axiomatic dialecticism permeates virtually the remainder of the subsequent work of Lewin, particularly notable highlights of which include his American book on a "dynamic theory of personality" (Lewin, 1935) or, somewhat earlier, his programmatic —and, again, not sufficiently well ready and absolutely not "digested" by the scholarly community of our time- treatise on the transition from "aristotelian" to "galillean" mode of thinking in biology and psychology (Lewin, 1930), not impeccably translated into English (e.g., German Übergang in the very title rendered as "conflict" seems highly problematic and confusing) and immediately published in translation (Lewin, 1931), as well as included as the very first chapter in his volume of selected papers (Lewin, 1935). In pretty much the same spirit, Kurt Koffka wrote his final and, arguably, the best book: the masterpiece, the 
author's "swan song" and the opus magnum that came out just a few years before his death in 1941 (Koffka, 1935).

In the context of the present discussion of "cultural-historical Gestalt psychology", it is most interesting to note that Koffka started his work on the book in the Soviet Union, during his research trip to Central Asia in 1932 as a member of a multinational team of researchers led by Vygotsky (in Moscow) and Luria (on the ground) (Harrower, 1983; Yasnitsky, 2013). Curiously enough, Koffka proved to be a mature researcher sensitive to cultural and social issues way more than the Soviet originators of the "cultural-historical theory", Vygotsky and Luria, and his field study of local subjects' performance on the visual perception and, specifically, optical illusions in effect undermined and refuted earlier "sensationalist" findings of Luria of his preceding expedition to the same area made a year before. This situation was recently discussed in terms of the "Luria-Koffka controversy of 1932” (Lamdan \& Yasnitsky, 2016). A most recent rigorous experimental study on a "conceptual (non)replication of Luria" in effect corroborated Koffka's findings (Arunkumar, Van Paridon, Ostarek, \& Huettig, 2021). Koffka’s book of 1935 bears certain traces of his collaboration on this field study in the Soviet Uzbekistan—see, for instance, an example of, in Koffka's own words, "an experiment which I made in the summer of 1932 in a small village in Uzbekistan in Central Asia" (Koffka, 1935, pp. 32-33) —and its argument appears to have largely been shaped by the experience of this research and, even more importantly, his dealings with Soviet psychologists and Koffka’s feelings of sincere sympathy toward them mixed with the explicit criticism of their Soviet ideological indoctrination and idiosyncrasies; for Koffka's "first-person speech" testimony, see specifically the entire chapter "The Russian-Uzbekistan Expedition" in the book by Harrower (1983, pp. 143-164).

Finally, I would argue that both Wertheimer and Köhler shared a great deal of the historical and dialectical "sentiments" of the kind, which can be supported by an array of their texts—such as, for instance, Köhler's discussion of "psychology and evolution" in the 1950 publication that can be found in the book by Henle (1961)—although, perhaps, in not quite an explicit form as expressed in the writings of Koffka and Lewin. This claim as it stands remains, however, a subject for an exciting future investigation.

\section{Activity and Actions Research}

Another foundational idea that Soviet Marxism importantly contributed to this science is the notion of "activity" (as popularized, for instance, in the later works of Aleksei N. Leontiev), yet not in the merely declarative forms and essentially behaviorist methodology of scientific research-for discussion and, specifically, the criticism of Leontiev by his Soviet associates Gal'perin and Bozhovich, see 
Yasnitsky (2021c). A ground-breaking, innovative, and breakthrough idea of "activity" - with explicit reference to the marginally psychological/anthropological works of Karl Marx-was introduced in psychology by Sergei Rubinstein and became the distinct core and trademark of the "Soviet Marxist" approach for decades and generations to come. Furthermore, Rubinstein's "activity approach" unites together a wide range of psychological notions by virtue of his insistence on the inseparable unity of "activity" and "consciousness" as "conscious activity" (Yasnitsky, 2021c), which is so easy to declare, but extremely difficult to follow, in empirical psychological research as the example of Leontiev and virtually all his followers (aka the Leontiev's clan) clearly demonstrates: the critique of the Leontievian tradition and research practice by one of Leontiev's closest associates is particularly telling (Galperin, 1995).

In this respect, it is highly interesting to make a systematic comparison of the "activity" proposal in the theoretical writings of the Soviet advocates for this approach with Kurt Lewin's empirical experimental studies on affect and action within the Berlin Circle of the 1920s-1930s. Given Soviet scholars' programmatic "activity" stance, this might explain their strong interest in Lewin's "actions" experimentation that would provide his Soviet peers with the concrete knowhow and technologies of research of this_- "activity/action" - kind. This hypothesis is quite plausible, it seems, but requires considerable further investigation and verification.

\section{Philosophical and Methodological Basis}

Indeed, as noted above, the interconnections between Lewin and Reichenbach are numerous, diverse, well documented, and well researched (Heis, 2013; Padovani, 2013; Wittmann, 1998). Furthermore, the whole logic and the style of their thinking were quite alike. For instance, it has been noted that "In the early 1920s, Hans Reichenbach and Kurt Lewin presented two topological accounts of time that appear to be interrelated in more than one respect. Despite their different approaches, their underlying idea is that time order is derived from specific structural properties of the world. In both works, moreover, the notion of genidentity-i.e., identity through or over time-plays a crucial role. Although it is well known that Reichenbach borrowed this notion from Kurt Lewin, not much has been written about their relationship, nor about the way Lewin implemented this notion in his own work in order to ground his topology" (Padovani, 2013, p. 97).

The Lewin-Reichenbach duo leads us to another major figure of the philosophical landscape of contemporary German thought: Ernst Cassirer, a great philosopher of the Neo-Kantian tradition. At this point, it is worthwhile to recall the name of another Neo-Kantian philosopher, Alois Riehl, a "Berliner" from 1905 
and Adhémar Gelb’s "primary dissertation supervisor", "who was a profound influence not only on the first generation of Gestalt psychologists but also on the philosophers who formed the nucleus of the unity of science wing of logical positivism including Hans Reichenbach and Herbert Feigl" (Devonis, 2012). Curiously, Cassirer, the "last German idealist philosopher", as he is often referred to and a former student of the leading philosopher and-among a few othersa founder of German Neo-Kantianism Hermann Cohen, was a cousin of another member of the Gestaltist network, Kurt Goldstein, and his influence on the latter's thought was also quite notable. Finally, this brings us back to another philosophical figure: Sergei Rubinstein, a doctoral graduate of Marburg University of 1913/14, Cassirer's associate and correspondent (Dmitrieva, 2016), and, reportedly, one of the best students and "favorites" of Cohen. Subsequently, it was on his solid Neo-Kantian philosophical foundation that Sergei Rubinstein erected the edifice of "Soviet Marxist psychology" (Yasnitsky, 2021c). Apparently, we are dealing here with a closely interlinked network of philosophers, medical doctors, psychologists, and epistemologists—-most of them to a larger or smaller degree rooted in Neo-Kantian philosophical tradition-which presents yet another exciting challenge for a researcher of the Gestaltist network in all its complexities and interrelations: personal, social and, perhaps most importantly, theoretical and methodological ones.

\section{Epilogue: The Contours of Transdisciplinary Pragmatic Anthropology}

In sum, the goal of this small paper and its immediate "prequel" (Yasnitsky, 2021b) was a discussion of three main theses: first, a revision of the history of the Gestalt community of scholars (and their associates) is needed from the perspective of "informal personal networks" and superindividual "circles" of its individual members; second, such a revision of history will inevitably lead to a revision of the theory that these individuals cumulatively proposed and developed; and, third, this new vision of the theory is based on a set of a few shared ideas and principles-not necessarily wholeheartedly shared and supported by all the members of the network and quite possibly contested by some of them-which I propose to derive from those historically existing intellectual interlinks between Soviet Marxists, German (even broader European Continental) Gestaltists and their American like-minded peers, students, and supporters.

In retrospect, the two implicit protagonists of this story so far have been Lev Vygotsky and Kurt Lewin: the lifetime intellectual and personal interconnections between the two, their legacies, and their contributions are relatively clear and well researched. Yet, subsequent research on the larger network of Soviet, German, and American scholars will reveal the richness of the interlinks within the network and its personal-professional hubs (the circles), thus, leading us to 
a better understanding of the full range and the richness of its integrative intellectual potential. This potential, then, will serve as a foundation for a dramatic reconstruction of this field of knowledge in the 21 st century as a truly holistic project, its general theory, original idiosyncratic research methodology, and methods of systematic knowledge production, and, finally, ground-breaking social practice in a wide range of fields such as medicine, health care, industry (e.g., personnel selection, workforce wellbeing, and workplace safety), education and training, counseling, etc.

We are on the verge of a great breakthrough. The "new psychology" is possible; its future contours are conspicuous. There is no need to worry that this "new psychology" might eventually turn into a future "pragmatic anthropology" (Kant, 2006) as a transdisciplinary union and unity of the disciplines of psychology, anthropology, philology (including linguistics), philosophy, and allied fields (Yasnitsky, 2021d). This will be a truly new, 21st-century field of knowledge about human beings that will resemble the old ones no more than the Ursa constellations resemble a couple of cute pandas in the local zoo.

Keywords: Soviet Marxist psychology, Soviet Gestaltism, Cultural Anthropology of Personality, Pragmatic Anthropology, transdisciplinarity.

\section{References}

Arunkumar, M., Van Paridon, J., Ostarek, M., Huettig, F. (2021). Do illiterates have illusions? A conceptual (non)replication of Luria (1976). Journal of Cultural Cognitive Science, 1, 1-6.

Brown, J. F. (1929). The methods of Kurt Lewin in the psychology of action and affection. Psychological Review, 36(3), 200-221.

Brown, J. F. (1936). Psychology and the social order. New York: McGraw-Hill Book Company.

Byford, A. (2021). Pedology as occupation in the early Soviet Union. In A. Yasnitsky (Ed.), A History of Marxist Psychology: The Golden Age of Soviet Science (pp. 109-127). London \& New York: Routledge.

Devonis, D. C. (2012). Gelb, Adhemar. In R. W. Rieber (Ed.), Encyclopedia of the History of Psychological Theories. New York, NY: Springer. doi:10.1007/978-1-4419-0463-8_93

Dmitrieva, N. A. (2016). Novye shtrikhi k portretam filosofov. Dva pis'ma E. Kassirera k S.L. Rubinsteinu [New Details to the Philosophers' Portraits. Two Letters of E. Cassirer to S. Rubinstein]. Voprosy Filosofii, (2), 127-136.

Ellis, W. D. (1930). Gestalt psychology and meaning. Berkeley: Sather Gate Book Shop.

Freud, S. (1905). Drei Abhandlungen zur Sexualtheorie. Leipzig: Deuticke.

Galperin, P. I. (1995). Problems in the psychology of activity. Journal of Russian and East European Psychology, $33(4), 18-31$.

Harrower, M. (1983). Kurt Koffka: an unwitting self-portrait. Gainsville: University Presses of Florida, Pp.xvi-334.

Heis, J. (2013). Ernst Cassirer, Kurt Lewin, and Hans Reichenbach. In N. Milkov (Ed.), The Berlin Group and the philosophy of logical empiricism (pp. 67-94). Dordrecht: Springer.

Henle, M. (Ed.). (1961). Documents of Gestalt psychology. Berkley and Los-Angeles: University of California Press.

Kant, I. (2006). Anthropology from a pragmatic point of view (1798) (R. B. Louden, M. Kuehn, Eds.). Cambridge: Cambridge University Press.

Kaufmann, W. A. (1950). Nietzsche: Philosopher, Psychologist, Antichrist. Princeton, NJ: Princeton University Press.

Keler, V. (1930). Issledovanie intellekta chelovekoobraznykh obezian [The investigation of the intellect of apes]. Moscow: Izdatel'stvo Kommunisticheskoi Akademii. 


\section{GESTALT THEORY, Vol. 43, No.3}

Koffka, K. (1921). Die Grundlagen Der Psychischen Entwicklung: Eine Einführung in Die Kinderpsychologie. Osterwieck a. Harz: A. W. Zickfeldt.

Koffka, K. (1922). Perception: An introduction to the Gestalt-theorie. Psychological Bulletin, 19(10), 531-585.

Koffka, K. (1924). The growth of the mind. An introduction to child-psychology. London: Routledge \& Kegan Paul.

Koffka, K. (1934). Osnovy psikhicheskogo razvitiia [Foundations of psychological development]. Moscow-Leningrad: Sotsekgiz.

Koffka, K. (1935). Principles of Gestalt Psychology. New York: Harcourt, Brace.

Köhler, W. (1925). The mentality of apes. New York: Harcourt Brace.

Köhler, W. (1938). The Place of Value in a World of Facts. New York: Liveright.

Krementsov, N. L. (1997). Stalinist science. Princeton: Princeton University Press.

Lamdan, E., Yasnitsky, A. (2016). Did Uzbeks have illusions? The Luria-Koffka controversy of 1932. In A. Yasnitsky, R. Van der Veer (Eds.), Revisionist Revolution in Vygotsky Studies (pp. 175-200). London \& New York: Routledge.

Lewin, K. (1922). Der Begriff der Genese in Physik, Biologie und Entwicklungsgeschichte. Eine Untersuchung zur vergleichenden Wissenschaftslehre. Berlin: Springer.

Lewin, K. (1930). Der Übergang von der aristotelischen zur galileischen Denkweise in Biologie und Psychologie. Erkentniss, 1(1), 421-466.

Lewin, K. (1931). The conflict between Aristotelian and Galileian modes of thought in contemporary psychology. Journal of General Psychology, 5(2), 141-177.

Lewin, K. (1935). A Dynamic Theory of Personality. New York \& London: McGraw-Hill Book Company.

Minton, H. L. (1988). J. F. Brown: Unsung Hero or Misguided Prophet in the History of Political Psychology? Political Psychology, 9(1), 165-173.

Padovani, F. (2013). Genidentity and topology of time: Kurt Lewin and Hans Reichenbach. In N. Milkov (Ed.), The Berlin Group and the philosophy of logical empiricism (pp. 97-122). Dordrecht: Springer.

Vertgeimer, M. (1987). Produktivnoe myshlenie [Productive thinking] (S. F. Gorbov, V. P. Zinchenko, Eds.). Moscow: Progress.

Vygotskii, L. S., Luria, A. R. (1930). Etiudy po istorii povedeniia. Obeziana. Primitiv. Rebionok. [Studies in the history of human behavior. Ape, primitive, child]. Moscow: Gosudarstvennoe izdatel'stvo.

Vygotskii, L. S. (1930a). Predislovie k russkomu izdaniiu [Introduction to Russian edition]. In V. Keler, Issledovanie intellekta chelovekopodobnykh obez'ian (pp. i-xxix). Moscow: Izdatel'stvo Kommunisticheskoi Akademii.

Vygotskii, L. S. (1930b). Strukturnaia psikhologiia [Structural psychology]. In B. A. Fingert, M. L. Shirvindt (Eds.), Osnovnye techeniia psikhologii [Main strands in psychology] (pp. 84-125). Moscow: GIZ.

Vygotskii, L. S. (1934). Problema razvitiia v strukturnoi psikhologii [The problem of development in structural psychology]. In K. Koffka, Osnovy psikhicheskogo razvitiia (pp. ix-lvi). Moscow, Leningrad: Gosudarstvennoe sotsial'no-ekonomicheskoe izdatel'stvo.

Vygotsky, L. S., Luria, A. R. (1993). Studies on the History of Behavior: Ape, Primitive, and Child. Hillsdale, NJ: Lawrence Erlbaum.

Wertheimer, M. (1910). Musik der Wedda. Sammelbände Der Internationalen Musikgesellschaft, 11, 300-309.

Wertheimer, M. (1912). Über das Denken der Naturvölker: I. Zahlen und Zahlgebilde [On the thinking of aboriginal peoples: I. Numbers and numerical structures]. Zeitschrift Für Psychologie, 60, 321-378.

Wertheimer, M. (1925). Drei Abhandlungen zur Gestalttheorie. Erlangen: Verlag der Philosophischen Akademie.

Wertheimer, M. (1945). Productive thinking. New York: Harper and Brothers.

Wittmann, S. (1998). Das Frühwerk Kurt Lewins. Zu den Quellen sozialpsychologischer Ansätze in Feldkonzept und Wissenschaftstheorie. Frankfurt: Peter Lang Verlag.

Yasnitsky, A. (2012). Revisionist revolution in Vygotskian science: Toward cultural-historical Gestalt psychology. Guest editor's introduction. Journal of Russian and East European Psychology, 50(4), 3-15.

Yasnitsky, A. (2013). Psychological expeditions of 1931-1932 to Central Asia. Chronicle of events in letters and documents. PsyAnima, Dubna Psychological Journal, 6(3), 114-166.

Yasnitsky, A. (2014). Field theory. In T. Teo (Ed.), Encyclopedia of Critical Psychology (pp. 730-733). New York: Springer.

Yasnitsky, A. (2016). A transnational history of 'the beginning of a beautiful friendship': The birth of culturalhistorical Gestalt psychology of Alexander Luria, Kurt Lewin, Lev Vygotsky, and others. In A. Yasnitsky, R. Van der Veer (Eds.), Revisionist Revolution in Vygotsky Studies (pp. 201-226). London \& New York: Routledge. 
Yasnitsky, A., Van der Veer, R. (2016). 'Lost in translation': Talking about sense, meaning, and consciousness. In A. Yasnitsky, R. Van der Veer (Eds.), Revisionist Revolution in Vygotsky Studies (pp. 229-239). London \& New York: Routledge.

Yasnitsky, A. (2019). Vygotsky's Science of Superman: From utopia to concrete psychology. In A. Yasnitsky (Ed.), Questioning Vygotsky's Legacy: Scientific Psychology or Heroic Cult (pp. 1-21). London \& New York: Routledge.

Yasnitsky, A. (Ed.). (2021a). A History of Marxist Psychology: The Golden Age of Soviet Science. London \& New York: Routledge.

Yasnitsky, A. (2021b). Cultural historical gestalt theory and beyond: A new history (and theory) of the informal personal network' of intellectuals is needed. Gestalt Theory - An International Multidisciplinary Journal.

Yasnitsky, A. (2021c). Sergei Rubinstein as the founder of Soviet Marxist psychology: "Problems of psychology in the works of Karl Marx" (1934) and beyond. In A. Yasnitsky (Ed.), A History of Marxist Psychology: The Golden Age of Soviet Science (pp. 58-90). London \& New York: Routledge.

Yasnitsky, A. (2021d). Scientific revolution without any revolution whatsoever: The psychology of the 21st century as 'eternal return' to its roots. Presented at the Guest Lecture, United Arab Emirates University, Al Ain. Retrieved from http://individual.utoronto.ca/yasnitsky/texts/Yasnitsky_2021_revNoRev.pdf

Zavershneva, E. (2014). The Problem of Consciousness in Vygotsky's Cultural-Historical Psychology. In A. Yasnitsky, R. Van der Veer, M. Ferrari (Eds.), The Cambridge Handbook of Cultural-Historical Psychology (pp. 63-97). Cambridge: Cambridge University Press.

Anton Yasnitsky, United Arab Emirates University, Al Ain, UAE.

E-mail: anton.yasnitsky@gmail.com

Orcid: 0000-0002-9574-535X 
